\title{
Applicability of the Student Course Experience Questionnaire (SCEQ) in an African Context: The Case of Nigerian Universities
}

\author{
Nifarta Peingurta Andrew \\ University of Peloponnese, Greece
}

\begin{abstract}
Student's perceptions surveys of university course experiences and learning environments has been part of quality evaluation in higher education in the western world, especially Australia and UK for the purpose of accountability, learning improvements or both. In Africa, particularly in Nigeria, it has not been so. Therefore this article examines the factor structure of a modified student's course experience questionnaire (SCEQ) with Nigerian undergraduate students to determine its applicability in an African context and also to investigate the similarities and differences in student's perceptions across different variables. It is based on a survey of 3,400 undergraduate students of all levels from five degree courses in faculty of sciences of 17 universities in Nigeria. Findings from exploratory factor analysis supports the scale structure of the nine subscales of a modified version of SCEQ (good teaching, clear goals, course level materials \& resources, emphasis on independence, appropriate workload, appropriate assessment, surface learning strategy, deep learning strategy and generic skills). This study could provide a basis for gender, degree courses, level of study, cross university, and international benchmarking. While there was variation of student's perception across many variables, students who perceived their courses and learning environment most favorably adopted a deep learning strategy, acquired better generic skills and were most satisfied with their courses as shown by correlation analysis. This information could be useful in informing the design of degree coursespecific programs.
\end{abstract}

\section{Introduction}

In Africa, especially the Nigerian higher education system, a considerable amount of time, resources and energy is being spent on universities academic programme accreditation periodically. The National University Commission (NUC) go round all the Nigerian universities in order to evaluate the quality of programmes run within the universities as part of quality evaluation, assessment and assurance of higher education [1]. The programmes are evaluated and scored based on the following criteria: staffing ( 32 points), academic content ( 23 points), physical facilities (25 points), library (12 points), funding, (5 points), employer's rating (3 points). From the criteria mentioned above, none focuses on the student's legitimate voices and no attention is being given to the student's perception of the quality of their course experiences and learning environment in these universities. Moreover, the results of these accreditation exercises were merely used for university rankings purposes only, which most often does not translate to quality programme, quality course experience, quality assessment procedures and quality learning improvement across these universities. See [2].

In contrast, universities around the world are exploring the use of teaching and learning performance indicators that solicits for student's perceptions about the quality of aspects of their course experiences, teaching and learning environment for performance - based funding, learning improvements and for benchmarking purposes [3], [4], [5] and [8]. For example in countries like Australia, the Graduate Career Council of Australia has since 1993 included the Course Experience Questionnaire (CEQ) [6], [7] as part of its annual Graduate Destination Survey for the improvement of the quality of teaching in the Australian higher education sector (See www.avcc.edu.au/students/gradlink/GCCA/index.ht $\mathrm{m})$ and even UK has also developed a similar national survey (see www.hefce.ac.uk/learning/nss/). Apart from these, the results of the CEQ are used widely by a range of stake holders, including the Australian Commonwealth Government, researchers in higher education, prospective students and tertiary institutions via the Good Universities bulletin.

Perusing through bulk of research done in the area of quality evaluation in higher education in Nigeria, very few solicited for the perception of students on issues of quality in higher education and even among the few; only a very negligible number did an extensive quantitative work in the area of quality evaluation of teaching and learning environment in higher education in Nigeria, see [14]. In view of the above, this study tries to address this problem by entirely soliciting for the student's perception of the quality of aspects of their course experiences and learning environment, using the Student Course Experience Questionnaire (SCEQ) which we 
developed according to the style of questions found in [6], [7] and [10] with the view of examining the applicability and factor structure of a modified version of the SCEQ when used in an African context with undergraduate students from Nigeria. We also explored variations and similarities of student's perceptions across type of university, university generation, level of study, degree course of study and gender. The study also demonstrates the link between the student's perception of the quality of aspects of their course experiences and learning environments with their learning strategy, skills acquired and their general satisfaction with their courses.

\section{Student's perception of quality of course experiences and learning environment}

Student perception studies are intended to be used as an indicative source of information about the student's experience from their own perspective and judgment. Being active beneficiaries of the teaching and learning that goes on in the university system, their opinion about the quality of their experiences and learning environment on which they are validly able to comment on provides insights as to how and where to improve the quality of courses and learning environment in higher education system. Most recent researchers in the area of student evaluation of quality in higher education have focused on student's perceptions of course experiences and learning environment across their entire degree and how these perceptions are related to approaches to study and subsequent learning outcomes. For example, the CEQ is derived from the student learning framework, which holds that student's approaches to study are contingent upon both their prior experiences of teaching and learning and their perception of current learning context, in turn affecting learning outcomes [8], [9]. The CEQ assess a range of graduate's perceptions related to teaching and learning as well as overall satisfaction as validity in a variety of settings. [10], [11]. Similarly, the Student Course Experience Questionnaire (SCEQ) [8] and [12] focuses on current students not graduates and sought to establish inter-rater agreement within faculties for each of the SCEQ scales, justifying aggregation of lower level scores to represent scores at the higher level; thereby making the SCEQ scales to be used as performance indicators of undergraduate teaching quality at the faculty level. [8] Also demonstrated that the SCEQ replicated the factor structure of the CEQ showing that the SCEQ has a clear, interpretable factor structure for undergraduate students.

On a general note, most studies using the Student Course Experience Questionnaire (SCEQ) focus on the student's perception of the quality of teaching, clarity of goals and standards, appropriate workload, appropriate assessment, independence, and generic skills; and how these perceptions relate subsequently to the student's approaches to learning. Students have been shown to adopt either a surface approach to study (focusing on short term reproduction) or a deep approach to study (focusing on longer term understanding) [9].

There is a substantial body of literature confirming the factor structure of both the CEQ and SCEQ within teaching and learning context in the west [6], [7], [10] and [15] and the scales used by [16] collectively defined a single higher-order factor that could be interpreted as a measure of perceived academic quality. The CEQ and SCEQ have been used within the context of perceived academic quality for benchmarking, as a performance indicator, for summative funding and formative purposes [8]. It has also been used by individual universities to formatively evaluate and improve their undergraduate programs [5] and because there is evidence showing that students are best placed to evaluate many aspects of teaching and learning, and their own ratings are valid, multidimensional and reliable [17], student course experience can be considered to be quite strongly related to qualities of the actual study context.

\section{The African context - Nigerian universities}

In Africa most especially Nigeria, education is accepted to be the major instrument for promoting socio-economic, political and cultural development [18]. Universities in particular, educate future leaders and develop the high-level technical capacities that underpin economic growth and - development. Therefore, the main purpose and relevance of university education according to [19] is to provide the man power that is much needed to accelerate the socio-economic development of the nation.

Having said this, what goes on in the universities the quality of teaching and learning, the student's course experiences, and their perceptions of the learning environment must be of great importance to the nation as well.

Studies carried out by [19] revealed some striking truth about the management of university education in Nigeria; where it was revealed that financial crisis, poor infrastructure, brain-drain, erosion of university autonomy, graduate unemployment, volatile and militant student's unionism, secret cults, examination malpractices, and sexual harassment constitutes to myriads of problems militating against effective management of the university system.

In response to the above problems of the university system, the National Policy on Education in 2004 came up with a policy that contributes to national 
development through high level manpower training by acquiring both physical and intellectual skills which will enable individuals to be self-reliant i.e investing in physical capital and closing the gap in capital [20].

But, [21] argued that successful development entails more than investing in physical capital or closing the gap in capital. It also entails acquiring and using knowledge through three major tasks - namely:

- Acquiring and adapting global knowledge in order to create knowledge locally.

- Investing in human capital to increase the ability to use and absorb knowledge.

- Investing in technologies to facilitate both acquisition and the absorption of knowledge.

Interpreting the above argument, we can deduce that there is therefore need for higher institutions of learning such as the universities to also consider the issue of quality in relation to teaching and learning environment more seriously.

In this study we are more concerned about the quality of student's course experience and learning environments, which is usually the focus of studies and research in the western world when it comes to higher education researches but is yet untapped in many higher education researches in Africa, particularly in Nigeria.

\section{Methodology}

\subsection{Sample}

Nigeria has a university system that is categorized in to three types (private, state and federal universities) and in to five generations $\left(1^{\text {st }}\right.$, $2^{\text {nd }}, 3^{\text {rd }}, 4^{\text {th }}$, and $5^{\text {th }}$ generations). 3,400 questionnaires were randomly administered to undergraduate students of the faculty of sciences in five degree courses at all levels $\left(1^{\text {st }}, 2^{\text {nd }} 3^{\text {rd }}\right.$ and $4^{\text {th }}$ level $)$ [1], [2]. The survey covered 17 out of $92(18.5 \%)$ Nigerian universities representing the six geo-political zones of Nigeria in the period April-July, 2008; which marks the end of the $2007 / 2008$ session in the Nigerian higher education system. A total of 2,221 usable responses (response rate of $65.3 \%$ ) were obtained, and a minimum institutional response rate of $30 \%$ was also achieved. The whole survey comprised of $41.7 \%$ and $32.6 \%$ male and female response rate respectively. The university type response rate stood approximately at $7.4 \%$ for private universities, $22.4 \%$ for state universities and $35.6 \%$ for federal universities. $9.5 \%$ of the responses came from first year level students, $13.4 \%$ from the second year level students, $20.9 \%$ from the third year level students and $21.6 \%$ from the final year students. Course response rate were, $22.4 \%$ for chemical sciences, $15.5 \%$ for biological sciences,
$9.8 \%$ for computer sciences, $16.7 \%$ for mathematical sciences and $0.9 \%$ for "others". Finally, 9.6\% responses were for $1^{\text {st }}$ generation universities, $18.4 \%$ for $2^{\text {nd }}, 18.1 \%$ for $3^{\text {rd }}, 11.9 \%$ for $4^{\text {th }}$ and $7.3 \%$ for $5^{\text {th }}$ generation universities.

\subsection{Data collection and instruments}

The modified SCEQ was available in paper version and was made up of 61 items corresponding to good teaching, clear goals, course level materials $\&$ resources, independence, appropriate workload, appropriate assessment, surface learning strategy, deep learning strategy, generic skills and the last item measures the general satisfaction of student with their degree courses. The students responded to each of the 61 items by indicating their agreement or disagreement with a particular statement along a 5point scale. $(1=$ strongly agree to $5=$ strongly disagree). Prior to the data collection for this study, the modified SCEQ was piloted among undergraduate students who came from different degree courses in the faculty of sciences of two universities in Nigeria. The items were slightly modified to fit in to the Nigerian context and the choice of the faculty of sciences was as a result of its common structure in all the selected universities in the sample as this will enable comparisons. Responses to negative items in the modified SCEQ were reversed before analysis. Additional data that provided some background information on the participants were also gathered.

\section{Analysis of findings}

Exploratory Factor Analysis (EFA) using SPSS 13.0 was used to test the structure of the first 60 SCEQ items. This included reliability analysis of each of the SCEQ scales using Cronbach's alpha coefficient [13] in order to determine the internal consistency of the scales. The EFA was conducted using principal components factor analysis (PCFA) with varimax rotation. The choice of principal component factor analysis provided a basis for direct comparison with results from [6] pilot study and with those from 1993 and 1994 and 1992 student samples in [7]. The varimax method of rotation is recommended where items are assumed to be correlated with each other. Given the evidence of positive and moderate inter-correlations demonstrated between the CEQ scales of [6], [7], a varimax rotation was deemed fit for the analysis of this study and a combination of the scree test and the eigenvalue $>1$ rule were used for determining the appropriate number of factors to be extracted. Factor loadings of 0.3 and above were selected for interpretations. Results from the reliability analysis of the scale of this study were compared with those from [6] and [7]. Results of the PCFA with varimax 
rotation method of the first 60 -item produced a very stable and virtually 9 factor solution which accounted for $57.6 \%$ of the variance. Two items of good teaching cross loaded on generic skills and one on course level materials and resources, while one item of the course level materials and resource cross loaded on emphasis on independence. One item of surface learning strategy cross loaded on appropriate assessment and one item of clear goals and standards cross loaded on good teaching. One item of appropriate workload cross loaded on emphasis on independence and one item of deep learning strategies cross loaded on generic skills. One item each of emphasis on independence cross loaded on good teaching and generic skills respectively. Finally, one item of appropriate assessment loaded on surface learning strategies. (Table of PCFA results and a copy of the modified SCEQ is not included because of lack of space, but can be sent on request).

Results of reliability analysis shows more convincing evidence of stability of the modified SCEQ used in this study when compared with those from [6] and with those from 1993, 1994 and 1992 student samples in [7]. See table 1 below.

Descriptive statistics and analysis of variance (ANOVA) were conducted at different levels of aggregation in order to examine the extent to which it revealed differences or degree of variation in student's perception of the quality of aspects of their degree courses and learning environment across different comparative groups. Significant variations in student's perceptions that revealed important patterns in student's perceptions were seen across the university types, university generations, degree courses, level of study and gender in almost all the sub-scale of the modified SCEQ. (Table of results not included here because they are many, but can be sent on request).

Correlation analysis was conducted between student's perception (measured by the sub-scales of the SCEQ) and reported learning strategies (measured by the surface and deep learning strategy sub-scales of the SCEQ) with results revealing two dimensions; one dimension significantly relating some of the SCEQ sub-scales positively to deep learning strategy and the other dimension significantly relating some of the SCEQ sub-scales negatively to surface learning strategy. Results obtained were compared with those from the 1993 sample of [7] and those cited in [7], see table 2 below for results. The result of correlation between student's perception and generic skills revealed strong significant positive correlation in almost all the SCEQ sub-scales and is being compared with the results from [7], see results in table 3 below. Similarly, correlation between student's perception and student's satisfaction with their degree courses (measured by the last item of the SCEQ) showed significant positive correlation as is being compared with results from [7], see table 4 for results.

\section{Discussion and contribution to knowledge}

Indicators of the quality of teaching and learning in higher education are constantly sought for by government, employers and the public for accountability and the demand for quality outcomes [4],[5], [8], [15] and [16]. One of such quality outcomes demanded is that students are adopting deeper learning strategies for a better overall learning experience. Knowing the contribution that student's perception of the quality of their course experience and learning environment can make on learning strategies, which in-turn improves their learning outcomes; it became important that such studies as this should also be conducted in a non-western context such as Nigeria. Findings provided support for the scale structure with Nigerian undergraduate students regardless of university type, university generation, degree courses, level of study and gender. Reliability coefficients of the scales of the modified SCEQ were consistent when compared with those from [6] and [7]. Although the PCFA showed that the 60 SCEQ items cross loaded on scales other than their hypothetical scales, such cross loadings were more from the good teaching scale, a pattern seen in previous studies [7]. Hence, the modified SCEQ is applicable for use with Nigerian undergraduate students.

An investigation of the variation of student's perception of quality of their course experiences and learning environment across comparative groups revealed some interesting results, among which a significant variation is revealed in all the SCEQ scales across university type and university generation. It has been revealed that students from the private type and $5^{\text {th }}$ generation universities perceived the quality of their course experiences and learning environments better in more scales than any of other type or generation of university. This result, though in the Nigerian context, is in resonance with the results found by [6] and [10] where they proved and concluded that departments teaching degree in the same subject in different institutions of higher education would vary in the quality of their experiences and learning environments. With reference to the variation across level of study, though this is a situation that is peculiar to this study only, yet we can deduce some important results that could be further elaborated in future studies. In studies like this we must expect variation in student's evaluation of the quality of their courses and learning environments across levels of their studies. Student's of higher levels are expected to perceive their course experiences and learning environment better than 
students of lower levels, since they have been longer in the system than those in levels below them.

Results from this study therefore supported this expectation and those students from the final year level of studies evaluated better five sub-scales (clear goals, good teaching, appropriate workload, deep learning strategy and generic skills) out of the nine sub-scales of the instrument of this study while students from the first year level of studies perceived better four out of the same nine sub-scales (course level resource and facilities, emphasis on independence, appropriate assessment and surface learning strategy.

Some interesting results to note here is, because the first year level students are new to the university system, they perceived the adoption of a surface learning strategy better than students from other levels of studies. On the other hand, because the final year students have been in the university system for some considerable number of years, they perceived clarity of goal and the adoption of a deep learning strategy better than those from the other levels of studies. The two intermediate levels of studies did not evaluate any sub-scale better than the other levels. The evaluation of the sub-scales is distributed between the two extremes. These two extreme distributions suggests that at the port of entry in to the university system, the student's perception of the quality of their courses is bound to be shallow due to a little understanding of the system at such stage, but as they advance in level of studies their perception about same aspects begins to change to a deeper one because they must have gained a better understanding of the system than when they began.

This observation can as well be a basis for future research in to the ability of the Student Course Evaluation Questionnaire (SCEQ) to provide information about change or stability in student's perception of the quality of their courses and learning environment over time when a cohort of students is being considered from the first level of studies to the final level of studies in an institution.

There existed no significant variations across gender in all the sub-scales except for the appropriate assessment and the surface learning strategy. This could be ascribed to the fact that variation in the appropriate assessment and learning strategy across gender depends on the approach of an individual to them. The way a female student adopts a learning strategy and approaches examinations is certainly quite different from the way a male student will. Moreover, there have been records of gender disparity in many aspects of higher education in Nigeria. For example, in the aspect of accessibility and equity in higher education; there has been a standing gap between the male and the female students. Therefore in most of the higher institutions like the universities, there is more male representation than the females and this can surely affect and cause variation in any evaluation that is gender oriented in the Nigeria's university system.

An interesting finding of the correlation between student's perception and learning strategies in this study related all the scales to surface learning strategies negatively and to deep learning strategies positively; meaning that those students who perceived the quality of their course experience positively adopted a deep learning strategy and those students who perceived it negatively adopted a surface learning strategy. This finding is also consistent with those found in previous studies [6].

The positive strong correlation between the student's perception and the generic skills and that between the student's perception and overall satisfaction reveals that the more students perceived the quality of their course experience and leaning environment better, the more they are likely to acquire generic skills and the more they are also likely to be satisfied with their degree course of study.

\section{Conclusion and future work}

With the evidence of a stable structure of the modified SCEQ with the Nigerian undergraduate students, the SCEQ could be a reliable instrument for the evaluation of quality in higher education in an African context like Nigeria in terms of teaching quality, clear goals and standard, course level materials and resources, emphasis on independence, appropriate workload, appropriate assessment, learning strategies and generic skills. While perceptions of course experience and learning strategies varied among sub-groups of variables, differences could inform the specific needs of degree courses in the design of a new or re-design of current curriculum in Nigeria. Adopting the SCEQ in Nigerian universities will provide basis for international benchmarking purposes in the future. Future research on the construct validity using confirmatory factor analysis will further validate the factor structure of the SCEQ for use in Nigeria and benchmarking across Africa at large.

\section{References}

[1] NUC Monday Bulletin, (2008), Results of the November 2007 accreditation exercise; A publication of the office of the executive secretary of the Nigerian Universities Commission, 21 April 2008 Vol. 3, (16).

[2] National Universities Commission, (NUC, 2004). Report on the performance of the federal university system, in 2002. Presented at the special meeting convened by the Honorable Minister of Education on $12^{\text {th }}$ December, 2004. 
Table 1. Cronbach's Alpha Coefficient for the Present study compared with those from Ramsden, (1991), Wilson et al., (1997)

\begin{tabular}{|c|c|c|c|c|c|}
\hline & \multirow{2}{*}{$\begin{array}{c}\text { Ramsden } \\
(1991)\end{array}$} & $\begin{array}{c}|c| \\
\text { Student } \\
\text { CEQ scale }\end{array}$ & $\begin{array}{c}1993 \\
\text { student } \\
\text { sample }\end{array}$ & $\begin{array}{c}1992 \\
\text { student } \\
\text { sample }\end{array}$ & \multirow{2}{*}{ Present study } \\
\hline Clear goals & 0.80 & 0.82 & 0.82 & 0.76 & 0.72 \\
\hline $\begin{array}{c}\text { Course resources and } \\
\text { facilities }\end{array}$ & - & - & - & - & 0.73 \\
\hline Good teaching & 0.87 & 0.86 & 0.88 & 0.88 & 0.85 \\
\hline $\begin{array}{c}\text { Emphasis on } \\
\text { independence }\end{array}$ & 0.72 & 0.68 & 0.67 & - & 0.61 \\
\hline Appropriate workload & 0.77 & 0.75 & 0.74 & 0.69 & 0.79 \\
\hline $\begin{array}{c}\text { Appropriate } \\
\text { assessment }\end{array}$ & 0.71 & 0.74 & 0.73 & 0.70 & 0.65 \\
\hline Surface learning & - & - & - & 0.69 & 0.75 \\
\hline Deep learning & - & - & - & 0.67 & 0.73 \\
\hline Generic skills & - & 0.80 & 0.79 & 0.77 & 0.88 \\
\hline
\end{tabular}

Table 2. Correlations between learning strategies and student's perception of quality Wilson et.al., 1997 and Trigwell \& Prosser, 1991 (cited in Wilson et. al., 1997)

\begin{tabular}{|c|c|c|c|c|c|c|}
\hline & \multicolumn{2}{|c|}{ Surface learning strategy } & \multicolumn{3}{c|}{ Deep learning strategy } \\
\hline $\begin{array}{c}\text { Sub-scales of Course } \\
\text { Experience Instrument }\end{array}$ & $\begin{array}{l}\text { Trigwell } \\
\text { \&Prosser, } \\
(1991)\end{array}$ & $\begin{array}{l}\text { Wilson } \\
\text { et.al., } \\
(1993 \\
\text { student } \\
\text { sample })\end{array}$ & $\begin{array}{l}\text { Present } \\
\text { Study }\end{array}$ & $\begin{array}{l}\text { Trigwell } \\
\text { \&Prosser } \\
(1991)\end{array}$ & $\begin{array}{l}\text { Wilson } \\
\text { et.al., } \\
(1993 \\
\text { student } \\
\text { sample })\end{array}$ & Present Study \\
\hline Clear Goals & -0.24 & -0.29 & $-0.26^{* *}$ & 0.10 & 0.12 & $0.41^{* *}$ \\
\hline $\begin{array}{c}\text { Course Level } \\
\text { Resources }\end{array}$ & - & - & $-0.07^{* *}$ & - & - & $0.07^{* *}$ \\
\hline $\begin{array}{c}\text { Good Teaching } \\
\text { Emphasis on }\end{array}$ & -0.10 & -0.34 & $-0.29^{* *}$ & 0.15 & 0.24 & $0.43^{* *}$ \\
\hline $\begin{array}{c}\text { Independence } \\
\text { Appropriate Workload }\end{array}$ & -0.45 & -0.29 & $-0.19^{* *}$ & 0.02 & 0.19 & $0.05^{* *}$ \\
\hline $\begin{array}{c}\text { Appropriate } \\
\text { Assessment }\end{array}$ & -0.43 & -0.47 & $-0.51^{* *}$ & 0.17 & 0.21 & 0.01 \\
\hline Generic Skills & - & -0.20 & $-0.10^{* *}$ & - & 0.37 & 0.04 \\
\hline \multicolumn{2}{|c|}{$\mathrm{n}=2,221 ; * *$ correlation is significant at 0.01 level; correlation is significant at 0.05 (2-tailed). } \\
\hline
\end{tabular}

Table 3. Correlations between generic skills and student's perception of quality of course experiences and learning environments compared with results from Wilson et.al., 1997

\begin{tabular}{|c|c|c|c|c|}
\hline $\begin{array}{c}\text { Sub-scales of Course } \\
\text { Experience Instrument }\end{array}$ & $\begin{array}{c}\text { Wilson et.al., (1993 } \\
\text { student sample) }\end{array}$ & $\begin{array}{c}\text { Wilson et.al., (1994 } \\
\text { student sample) }\end{array}$ & $\begin{array}{c}\text { Wilson et.al., (1992 } \\
\text { graduate sample) }\end{array}$ & Present study \\
\hline Clear Goals & 0.33 & 0.30 & 0.29 & $0.51^{* *}$ \\
\hline Course Level Resources & - & - & - & $0.14^{* *}$ \\
\hline Good Teaching & 0.46 & 0.48 & - & $0.55^{* *}$ \\
\hline $\begin{array}{c}\text { Emphasis on } \\
\text { Independence }\end{array}$ & 0.41 & 0.40 & 0.10 & $0.12^{* *}$ \\
\hline Appropriate Workload & 0.16 & 0.15 & 0.20 & $0.10^{* *}$ \\
\hline Appropriate Assessment & 0.35 & 0.37 & $-0.08^{* *}$ \\
\hline
\end{tabular}


Table 4. Correlations between General Satisfaction with Course and the Sub-scales of the Course Experience Instrument compared with results from Wilson et.al., 1997

\begin{tabular}{|c|c|c|c|c|}
\hline $\begin{array}{c}\text { Sub-scales of Course } \\
\text { Experience Instrument }\end{array}$ & $\begin{array}{c}\text { Wilson et.al., (1993 } \\
\text { student sample) }\end{array}$ & $\begin{array}{c}\text { General Satisfaction with course } \\
\text { Wilson et.al., } \\
\text { (1994 student } \\
\text { sample) }\end{array}$ & $\begin{array}{c}\text { Wilson et.al., (1992 } \\
\text { graduate sample) }\end{array}$ & $\begin{array}{c}\text { Present } \\
\text { study }\end{array}$ \\
\hline Clear Goals & 0.55 & 0.55 & 0.50 & $0.42^{* *}$ \\
\hline Course Level Resources & - & - & - & $0.24^{* *}$ \\
\hline Good Teaching & 0.64 & 0.64 & - & $0.47^{* *}$ \\
\hline $\begin{array}{c}\text { Emphasis on } \\
\text { Independence }\end{array}$ & 0.54 & 0.51 & $0.11^{* *}$ \\
\hline Appropriate Workload & 0.33 & 0.36 & 0.17 & $0.14^{* *}$ \\
\hline Appropriate Assessment & 0.47 & 0.41 & 0.47 & $-0.12^{* *}$ \\
\hline Generic Skills & 0.50 & 0.51 & $0.66^{* *}$ \\
\hline
\end{tabular}

$\mathrm{n}=2,221 ; * *$ correlation is significant at 0.01 level; * correlation is significant at 0.05 (2-tailed).

Correlations $\geq 0.20$ are used for interpretations of results for all correlation analysis.

[3] Marsh, H.W., Rowe K.J., \& Martin, A., (2002) PhD Student's evaluation of research supervision, Journal of Higher Education, 73 (3), 313-348.

[4] Prosser, M. \& Barrie, S., (2003) Using a student focused learning perspective to strategically align academic development with institutional quality assurance, in: R. Blackwell \& P. Blackmore (Eds) Towards Strategic Staff Development in Higher Education (Buckingham, Open University Press).

[5] Barrie, S., Ginns, P. \& Prosser, M. (2005) Early impact and outcome of an institutionally aligned, student focused learning perspective on teaching quality assurance, Assessment and Evaluation in Higher Education, 30 (6), 641-656.

[6] Ramsden, P., (1991) A performance indicator of teaching quality in higher education: The course experience questionnaire, Studies in Higher Education, 16 (2), 129-150.

[7] Wilson, K. L., Lizzio, A. \& Ramsden, P., (1997) The development, validation and application of the course experience questionnaire, Studies in Higher Education, 22 (1), 33-53.

[8] Ginns, P., Prosser, M., Barrie, S., (2007) Student's perception of teaching quality in higher education: The perspective of currently enrolled students, Studies in Higher Education, 32 (5), 603-615.

[8] Ramsden, P., (2003) Learning to Teach in Higher Education ( $2^{\text {nd }}$ edn) (London, Routledge).

[9] Prosser, M., \& Trigwell, K., (1999) Understanding Learning and Teaching: The Experience in Higher Education (Buckingham, Open University Press).

[10] Richardson, J.T.E., (1994) A British evaluation of the course experience questionnaire, Studies in Higher Education, 19 (1), 59-68.

[11] Lawless, C.J. \& Richardson, J.T.E. (2002) Approaches to studying and perception of academic quality in distance education, Higher Education, 44 (2), 257-282.
[12] Webster, B.J., Chan, W.S.C., Prosser, M.T. \& Watkins, D. A., (2009) Undergraduate's learning experience and learning process: Quantitative evidence from the East, Higher Education 58 (1), 375-386.

[13] Cronbach, L.J., (1951) Coefficient alpha and the internal structure of tests, Phychometrika, 35 (3) 297 $334)$.

[14] Watkins D. and Akande A., (1992), Student Evaluations of Teaching Effectiveness; Nigerian investigation: Higher Education, 24 (4).453-463.

[15] Lizzio, A., Wilson, K., \& Simons, R., (2002) University student's perceptions of the learning environment and academic outcomes: Implications for theory and practice. Studies in Higher Education, 27 (1), $27-52$.

[16] Richardson, J.T.E., (2006) Investigating the relationship between variations in student's perception of their academic environment and variation in study behaviors in distance education. The British Journal of Education Psychology, 76(4), 867-893.

[17] Watchel, H. (1998) Student evaluation of college teaching effectiveness: A brief Review. Assessment and Evaluation in Higher Education 23(2) 191-211.

[18] Odekunle, K.S., (2001) Funding of university education under democratic rule in Nigeria: Problems and prospects. Proceedings of the $12^{\text {th }}$ general assembly of SSAN.

[19] Ekundayo, H.T \& Ajayi, I.A., (2009) Towards effective management of university education in Nigeria. International NGO Journal 4(8) 342-347 http://www.academicjournals.org/INGOJ ISSN 19938225(C) 2009 Academic Journals.

[20] Federal Republic of Nigeria (2004). National Policy on Education. Lagos: NERDC. 
Literacy Information and Computer Education Journal (LICEJ), Volume 1, Issue 3, September 2010

[21] Odia, L.O \& Omofunmwa, S.I., (2007) Educational system in Nigeria: Problems and Prospects. Journal of Social Science 14(1) 81-86. 